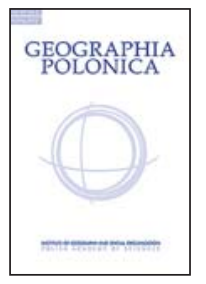

\title{
VARIABILITY OF THE PARTICULATE MATTER AIR POLLUTION OF POLISH CITIES WITH A PREDICTION UNTIL 2020
}

\section{Damian Łowicki}

Faculty of Geographical and Geological Sciences

Adam Mickiewicz University in Poznań

B. Krygowskiego 10, 61-680 Poznań: Poland

e-mail: damek@amu.edu.pl

\begin{abstract}
Air pollution with particulate matter is a serious problem in Europe, especially in Poland. Despite the fact that the issue of particulate air pollution concerns both big agglomerations and smaller towns, and even villages, due to the population density and chemical composition of the particulate matter, the actions to limit the concentration are focused on big cities. In this study the data for 30 Polish cities and urban agglomerations from 2000-2016 was analyzed to show the temporal and spatial variability of the pollutants level and to prepare the prediction until 2020. The analysis showed that although for most cities a decreasing trend was observed, there are a few cities that will not achieve the assumed level in 2020. Another fact is that for some cities that currently meet the average annual standards, the limits in 2020 are expected to be exceeded.
\end{abstract}

\section{Key words}

particulate matter $\cdot$ air pollution $\cdot$ Poland $\bullet$ cities $\bullet$ prediction

\section{Introduction}

In order to reduce the negative impact of the particulate matter (PM) on human health and the environment, the EU has introduced directives relating to the reduction of emission and air quality standards. One of them, the Directive on ambient air and cleaner air for Europe (EUR-Lex 2008) establishes a standard for PM10 to $40 \mu \mathrm{g} / \mathrm{m}^{3}$ (annual mean) and $50 \mu \mathrm{g} / \mathrm{m}^{3}$ (daily mean) and for
PM2.5 - $25 \mu \mathrm{g} / \mathrm{m}^{3}$ (annual mean). Poland, along with Bulgaria, belongs to the countries that fail to meet these standards the most frequently, contributing to approx. 50 thousand early deaths per year. In Poland in 2016, more than $90 \%$ of stations indicating concentrations above the annual PM limit were situated in urban areas. In the last few years, an excess number of days with exceedances has been noted in the majority of agglomerations, whereas in 2015, this issue concerned 
11 out of 12 Polish agglomerations. However, it should be remembered that this issue concerns equally the agglomerations and small towns and sometimes even small villages (GIOŚ 2017a). Among the 10 most polluted cities in EU countries with a high income, 6 cities, in the case of PM10 and 10 in the case of PM2.5, are situated in Poland (WHO 2016). Exposure to an elevated level of particulate matter has a significant influence on life expectancy. Research carried out in six cities of the United Stated indicates that the mortality is closely linked with very fine particulate air pollution (e.g. Dockery et al. 1993). The analyses for the city of Wroctaw showed that the estimated number of deaths in relation to the PM2.5 concentration amounted to as many as $150-166$ per 100 thousand inhabitants in 2014 (Sówka et al. 2016). The researches prove that particulate matter is much more dangerous for people in urban areas since they contain more metals and toxic organic compounds such as PAH (Langner et al. 2011), although the urban diversity, in terms of concentration and chemical composition of the particulate matter, is significant (Rogula-Kozłowska et al. 2014). Despite the fact that the number of the EU countries that fail to meet the standards for limit PM concentrations decreases, the current tendencies indicate that the exceedances still will be occurring in many countries by 2020 . In the case of PM10 averaged trend in annual mean concentrations for urban stations in EU in years 2000-2014 was - $-0.64 \mu \mathrm{g} /$ $\mathrm{m}^{3}$, and in the case of PM2.5 in years 20062014 the trend was only $-0.34 \mu \mathrm{g} / \mathrm{m}^{3}$ (EEA 2016).

The aim of this study is to assess the diversity of the state and trends for changes in 30 Polish urban areas. The analyses of particulate matter concentration in Poland are both an object of purely scientific research (Rogula-Kozłowska et al. 2014; Reizer \& JudaRezler 2016) and elements of monitoring and communication activity of the Polish Chief Inspectorate for Environmental Protection (GIOŚ 2011; Juda-Rezler \& Toczko 2016; GIOŚ 2017a); however, among them, there is no analysis for longer time sequences containing also a change prediction.

\section{Research area}

The particulate matter air pollution was analysed in 30 urban zones, i.e., Polish cities and urban agglomerations (Fig. 1). Their total surface area amounts to $6,159 \mathrm{~km}^{2}$, which constitutes approx. $2 \%$ of the country's area. The population in these zones amounts to approx. 11.6 million, which constitutes slightly over $30 \%$ of the country's population. The average population density amounts to 1,784 people $/ \mathrm{km}^{2}$, the highest population density is observed in Warsaw agglomeration - 3,393 people $/ \mathrm{km}^{2}$, whereas the lowest - in Rybnik and Jastrzębie Zdrój agglomeration - 977 people $/ \mathrm{km}^{2}$.

Among 161 measurement stations active in 2016, presenting the average daily data, almost $90 \%$ had urban character, $7 \%$ represented the suburban type and the rest - the rural type. About one-third of the urban-type stations are situated in urban zones (cities and agglomerations). The density of stations presenting the averaged data for $24 \mathrm{~h}$ per $100 \mathrm{~km}^{2}$ of the urban zone amounted to 2.5 in the case of PM10 and 1.1 for PM2.5. The cities of Silesian Voivodeship are characterised by particularly low density of the measurement network. In the case of PM10, this density amounts on average to 0.6 per each $100 \mathrm{~km}^{2}$.

\section{Materials and methods}

The first stage of the research was to gather data concerning the particulate matter concentration in urban zones. The data concerning the average daily particulate matter concentration for 106 and 50 measurement urban stations (respectively for PM10 and PM2.5) for 2000-2016 have been accessed from the GIOŚ (2017b). For the measurement of particulate matter, the methodology set out in Directive on ambient air quality and cleaner air for Europe (EUR-Lex 2008) is applied. In total 640,434 records were 


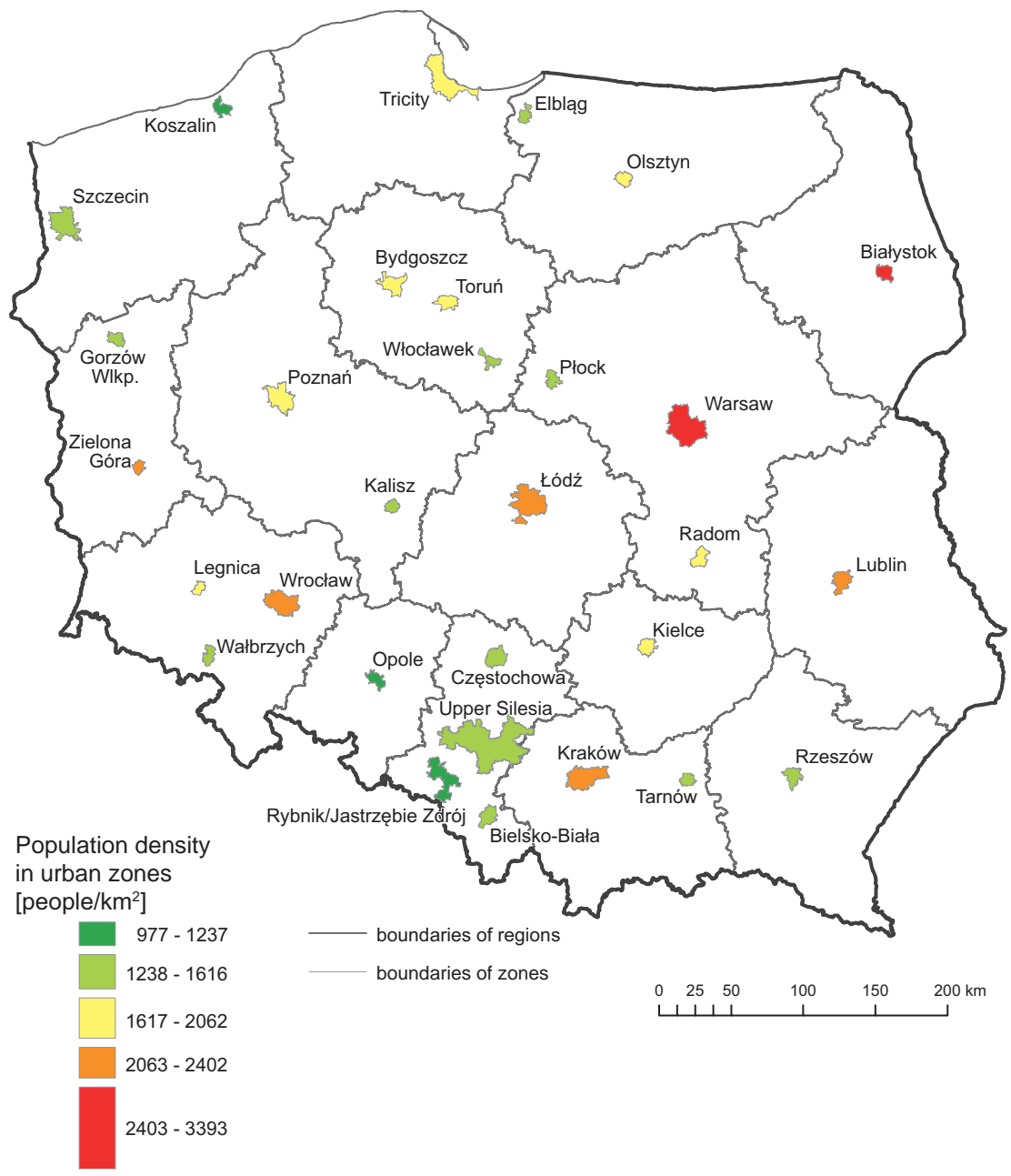

Figure 1. Distribution of the city zones analyzed and their population density

processed. The highest number of urban stations presenting the average daily data was situated in Warsaw agglomeration - 9 for PM10 and 4 for PM2.5, whereas the lowest number in Bielsko-Biała, Częstochowa and Kalisz - 1 for PM10 and PM2.5. The average daily data for each station were averaged for specific years and subsequently - for each one of 30 urban zones. Thereafter, the estimated particulate matter concentration in 2020 was calculated using trend analysis. This is a type of the regression analysis, where the observed values are the time series, in this case of PM concentrations. The result is the line described by calculated formula, its extension in the front can be used to make predictions. The average number of years taken into account in the case of PM10 amounted to 13, the minimal number is 9 ( 1 zone) and maximal - 17 (4 zones). In the case of PM2.5, the average number of years amounted to 8 , the minimal number - to 5 ( 1 zone) and maximal - to 13 (1 zone). In the prediction, only the admissible level for the given calendar year was analysed; neither the permissible frequencies of exceedance in the calendar year for PM10, nor the exposure concentration 
obligation and National Exposure Reduction Target for PM2.5 were taken into consideration. The obtained results were confronted with data on the emission of PM into the air. Their main source was Statistics Poland (GUS). Unfortunately, these statistics only cover emissions of air pollutants from plants especially noxious to air purity. This category of plants includes all organizational units specified by the Minister of Environment Protection on the basis of the amount of fees paid in 1986 for an annual emission of air pollutants. It means that these data do not cover the households and transport emissions which are responsible for the majority of PM pollution in the cities. Therefore, the described causes of PM concentration changes can be only the hypotheses.

\section{Results}

The average annual PM10 concentration between 2000-2016 for the urban zones and agglomerations amounted to $32.5 \mu \mathrm{g} /$ $\mathrm{m}^{3}$, whereas the first quartile concentration - to $24.1 \mu \mathrm{g} / \mathrm{m}^{3}$ and third quartile to 42.2 $\mu \mathrm{g} / \mathrm{m}^{3}$ (Fig. 2A). In the case of PM2.5, these values are lower and amount respectively to 24.3, 20.5, and $25.9 \mu \mathrm{g} / \mathrm{m}^{3}$ (Fig. 2B). In some cities the average annual concentration for years 2000-2016 is higher than annual statutory limits. In the case of PM10 concentration there is 4 such cities and in the case of PM2.5 even 10 .

The situation is particularly bad in the Silesia Voivodeship. In Upper Silesia, Rybnik and

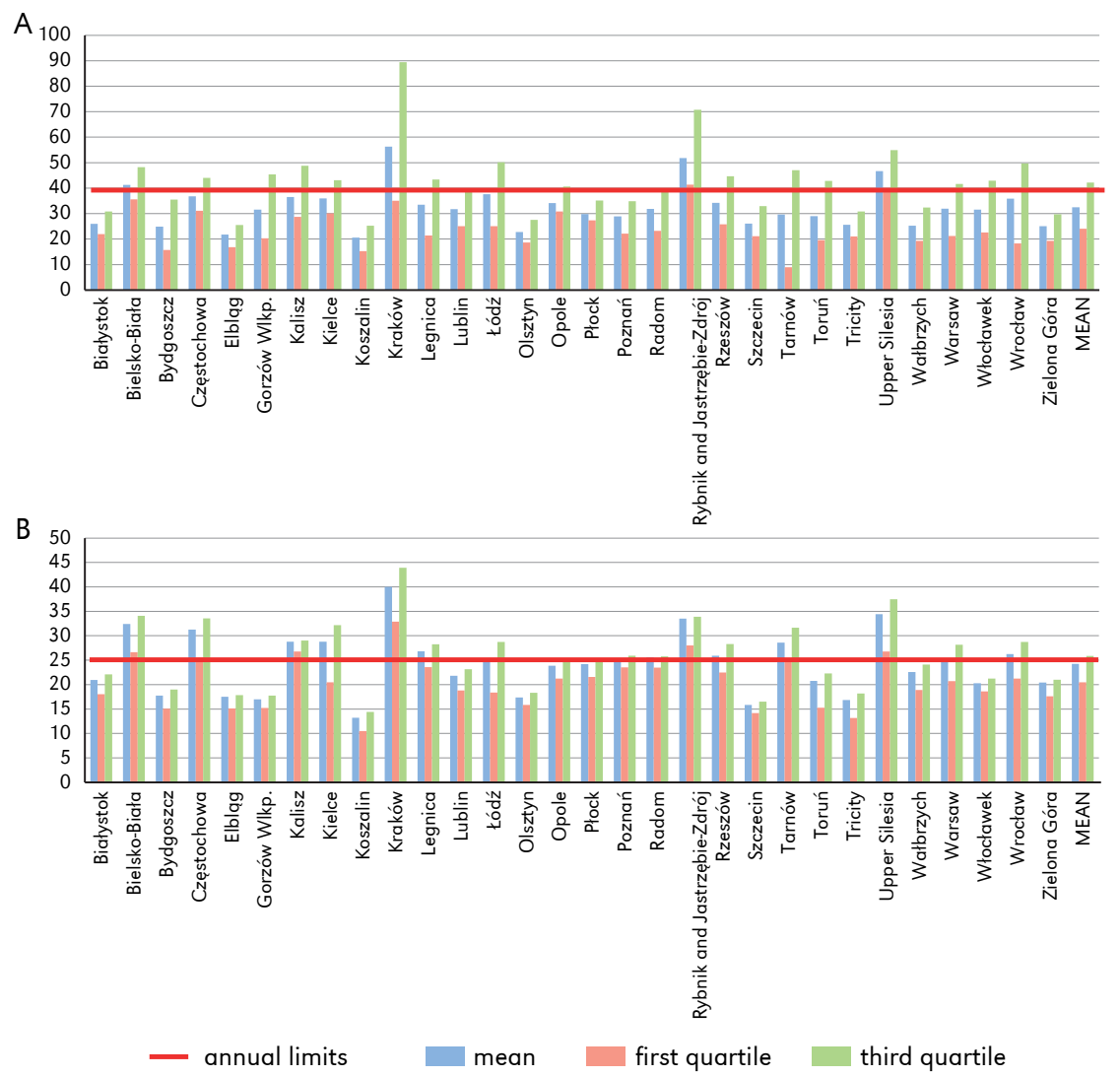

Figure 2. Diversity of Polish cities in terms of average annual concentration of PM10 (A) and PM2.5 (B) in 2000-2016 
Jastrzębie Zdrój and Bielsko-Biała agglomerations the average daily concentrations for years 2000-2016 reach the values of 300 $\mu \mathrm{g} / \mathrm{m}^{3}$ and more in the case of PM10 and $200 \mu \mathrm{g} / \mathrm{m}^{3}$ and more in the case of PM2.5. In the three agglomerations of this region the mean annual limits of PM10 and PM2.5 concentration are permanently exceeded. This is due to the very high level of PM emissions. In such cities as Dąbrowa Górnicza, Rybnik, Siemianowice Śląkie and Bytom the mean level of PM emission for years 2010-2016 from plants of significant nuisance to air quality on $\mathrm{km}^{2}$ is many times higher than mean emission in cities of Poland (GUS BDL). In the city of Dabrowa Górnicza this level is even ten times higher than mean value for all cities. Production of energy from fuel combustion is mainly responsible for this emission. In some cities, e.g. in Dąbrowa Górnicza also unorganized emission from mine and waste dumps is also very important (GUS BDL). A very bad situation also occurs in some cities outside the Silesia Voivodship. In Kraków, due to the overlapping of several factors, the situation is particularly bad. The first reason for high pollution is emissions caused by the operation of large industrial plants, including steel mills and combined heat and power plants. Although PM emission from plants of significant nuisance to air quality on $\mathrm{km}^{2}$ in this city decreased by more than half in 2010-2016, it is still higher than in the average Polish city (GUS BDL). The second reason is transportation. In Kraków, in 2010-2016, the number of vehicles increased by as much as 110,000 , which is the second result after Warsaw. Currently, there are over three times more cars on the streets of Kraków than in the average Polish city. The third reason is low volume of sales of heat energy converted into the volume of residential buildings. In 2010, it was lower than the average for Polish cities by $21 \%$, but later this ratio quickly decreased to less than $1 \%$ in 2016 . The dense medieval city center certainly hinders the development of district heating. The fourth factor affecting air pollution in this city is unfavorable relief. The city is located in the ground lowering, which makes it difficult to properly ventilate. Apart from Silesia Voivodeship and Kraków, there are also the Wrocław agglomeration, Częstochowa, Kalisz, Kielce, Legnica, Radom, Rzeszów and Tarnów that show excess PM2.5 concentrations. In the city of Tarnów bad situation is caused by level of PM emission, which in years 2010-2016 was 2.5 times higher than mean. Responsible for emission in this city are several factories, at the forefront with Grupa Azoty - manufacturer of nitrogen and compound fertilizers. In other cities of this group it is difficult to indicate one distinctive reason for air pollution.

In the vast majority of urban zones in Poland, a decreasing trend of the particulate matter concentration in the air is observed (Fig. 3). In 4 cities the average annual concentration of PM10 showed a statistically important increasing trend: Bydgoszcz agglomeration $\left(R^{2}=0.7\right)$, Elblag $\left(R^{2}=0.3\right)$, Koszalin $\left(R^{2}=0.3\right)$ and Wałbrzych $\left(R^{2}=0.4\right)$. In the case of these cities, the reason of increasing PM pollution is not the industry emission. In all these cities, with the exception of Koszalin, emission of particulate matter from plants of significant nuisance to air quality is decreasing. The main reason is the increase in emissions from households and transportation. Due to the increasing area of built-up areas, often scattered housing, the share of households heated individually is increasing. In these cities records a negative trend of sales of heat energy converted into the volume of residential buildings (GUS BDL). In addition, there are more vehicles in all cities. In Łódź, in years 2000-2016 the number of vehicles increased by 77 thousand, and in Watbrzych in 20132016 it has tripled (GUS BDL). The worst situation in terms of the trend for changes takes place in Bydgoszcz agglomeration where the average annual increase of PM10 level for 9 measurement years was the clearest $\left(R^{2}=0.74\right)$ and amounted to $2.2 \mu \mathrm{g} / \mathrm{m}^{3} /$ year. In some cities, especially where is only one measuring station, the reason of changing indications of PM10 pollution could be just technical. In many cities in Poland 
the measurements of PM2.5 were started later than measurements of PM10. In Elblag, both PM10 and PM2.5 measurements, were taken over by new station after 2009. This station was located closer to the city center, which could have caused the indications for PM10 since 2010 to be higher compared to PM2.5. In the case of PM2.5, the pollution has been increasing in Łódź agglomeration (Fig. 3), but this trend is not so clear $\left(R^{2}=0.2\right)$. One of the reason of the pollution increasing in Łódź is transportation. In years 2000-2016 the number of vehicles in this city increased by 77 thousand (GUS BDL).

In general, it should be noted that increases took place in zones with the lowest pollution levels such as Koszalin $\left(20.6 \mu \mathrm{g} / \mathrm{m}^{3}\right)$, Elblag $\left(21.8 \mu \mathrm{g} / \mathrm{m}^{3}\right)$, or Bydgoszcz agglomeration $\left(24.9 \mu \mathrm{g} / \mathrm{m}^{3}\right)$. An exception is the agglomeration of Łódź where both the average PM10 concentration between 2000-2016 and the average PM2.5 concentration between 2004-2016 was higher than the mean for Poland and at the same time, there was an increase in concentrations, although, it was minor and irregular. The bad situation takes place in particular in Kraków agglomeration where we observe the highest average concentrations (for PM10 between $2000-2016$ it is $56.3 \mu \mathrm{g} / \mathrm{m}^{3}$, and for PM2.5 between 2002-2016 it is $40 \mu \mathrm{g} / \mathrm{m}^{3}$ ) and, at the same time, the decreases are minor $\left(0.51 \mu \mathrm{g} / \mathrm{m}^{3}\right.$ for PM10 and $1.16 \mu \mathrm{g} / \mathrm{m}^{3}$ for PM2.5). A slightly better situation is observed in Rybnik and Jastrzębie-Zdrój agglomeration, in particular in the case of PM10 where the average annual particulate matter concentration is very high

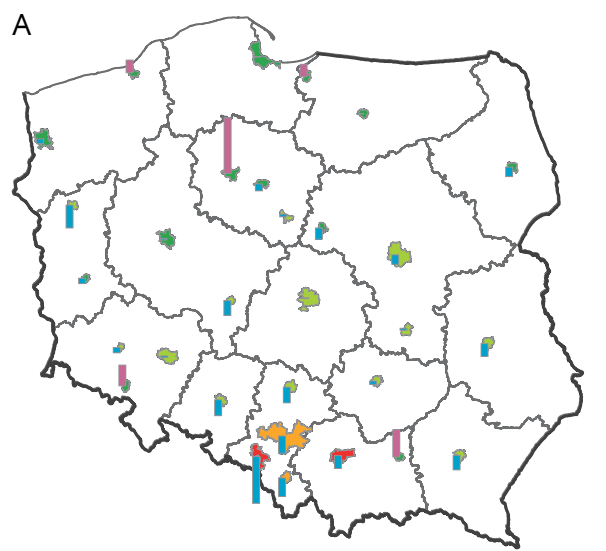

\section{Mean concentration of PM10}

$20.6-30.0$

$30.1-40.0$

$40.1-50.0$

$50.1-60.0$
B

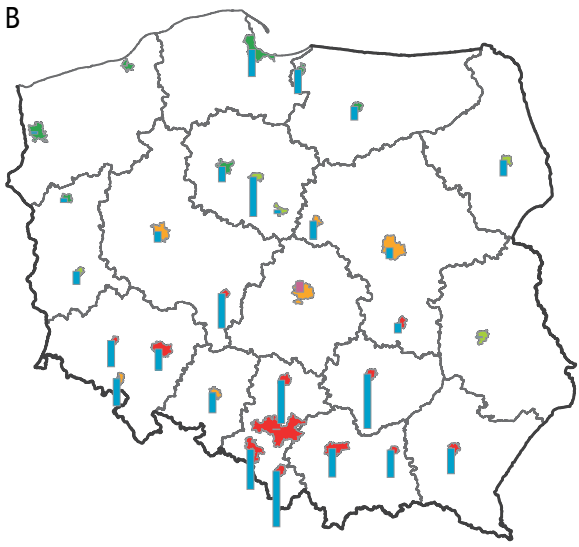

Mean concentration of PM2.5

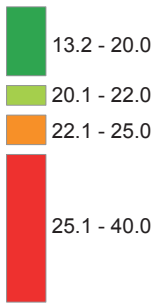

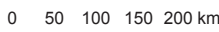

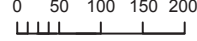

Trend $\left[\mu \mathrm{g} / \mathrm{m}^{3} /\right.$ year $]$

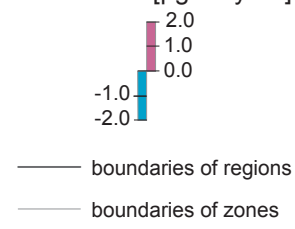

Figure 3. The average annual PM10 (A) and PM2.5 (B) concentrations in Polish urban zones and their changes between 2000-2016 
(51.8 $\left.\mu \mathrm{g} / \mathrm{m}^{3}\right)$ and the decrease amounts to almost $2 \mu \mathrm{g} / \mathrm{m}^{3}$ per year. The best situation takes place in the north of the country, in the Tricity agglomeration (Gdańsk, Gdynia and Sopot), in Olsztyn and in Szczecin. A good situation takes place also in Poznań and Zielona Góra. The decreasing trend in PM concentration in these cities results from a clear drop in emissions, especially in the case of Gdańsk, where the emission in years 2010-2013 was very high. A clearly decreasing trend in the case both, PM10 and PM2.5, could be also observed in cities Bielsko-Biała and Opole, despite that the PM concentration in these cities is usually higher than the mean for Polish cities. Assuming that the trend of changes continues in the future, there is probability that some cities will not reach the average annual statutory limits (Rozporządzenie Ministra Środowiska 2012), i.e. $40 \mu \mathrm{g} / \mathrm{m}^{3}$ for PM10 and $25 \mu \mathrm{g} / \mathrm{m}^{3}$ for PM2.5 (Tab. 1).

Based on the trends of changes and their expected effect in 2020, the division of cities into five groups was made. In the first group there was only one city. In BydgoSzCz the increasing trend of PM10 is very clear and keeping the limit in 2020 is very doubtful. The second group are the cities, where despite lack of a clear trend or the existence of a declining trend, the keeping the limits is doubtful. The third group are the cities, where despite the existence of an increasing trend, the limits are not threatened. Forth group are the cities, where are no clear trends and the limits are not threatened. Fifth group are the cities, where are the clear declining trends and the limits are not threatened. In the case of PM10, the worst situation is in cities: Bydgoszcz, Upper Silesia, Kraków, and Rybnik and Jastrzębie-Zdrój, Tarnów, while in the case of PM2.5 in: the Upper Silesia, Kraków, and Łódź agglomerations (Fig. 4). In the cities with the highest average concentrations, the annual decreases at the level of 0.5-0.7 $\mu \mathrm{g} / \mathrm{m}^{3}$ for PM10 and 1.2-0.0 - as in the case of Kraków agglomeration and Upper Silesia agglomeration are insufficient to reach the limits.

\section{Discussion and conclusions}

Despite the fact that the issue of particulate air pollution concerns both big agglomerations and smaller towns, and even villages, due to the population density and chemical composition of the particulate matter, the actions to limit the concentration are focused on big cities. Above-presented study shows that overall there is a decrease of PM pollution in Polish cities, but in many cases it not enough. Assuming that there will be no deviations from the average for the last 17 years, there will be several cities in Poland, where average annual air quality standards will be exceeded in 2020. Among them are the cities in which there are already exceedances, as well as the cities that did not have them so far. Unfortunately, the highest declines concerned mainly the cities with the highest particulate matter concentration. The main problem in the entire EU, in particular in Central and Eastern Europe, is heating houses using solid fuels, especially coal (EEA 2016). The most popular tools to decrease the level of air pollution is replacement of solid fuel fired boilers, thermo-modernization of buildings and using renewable energy sources. Poland is working on this issue, but so far it has been insufficient. The indicator of ecological effectiveness of investments in the Kraków agglomeration, one of the most polluted and the most engaged in Poland, was low. For years 2013-2015, in the case of replacement of solid fuel boilers, it amounted to about 93 thous. $€ / M g$ of PM10, and in the case of thermo-modernization of buildings up to 1.35 million. $€ / M g$ of PM10 (Sprawozdanie z realizacji... 2016). Taking into account the fact that by 2020 the PM10 emission in the Kraków agglomeration is to be reduced by $1,230 \mathrm{Mg}$ (Dziennik Urzędowy Województwa Małopolskiego 2017), the costs that need to be incurred are huge. Also, the measurement density at the level of 2.5/100 km² in the case of PM10 and $1.1 / 100 \mathrm{~km}^{2}$ for PM2.5 seems to be insufficient. A very low number of stations in cities 
Table 1. Changes in the average annual PM concentration in Polish urban zones between 2000 and 2016 along with a prediction for 2020. The cities are divided by dotted lines into five groups. Their description is placed in the text. Bold font indicates concentrations above the average annual norm

\begin{tabular}{|c|c|c|c|c|c|c|}
\hline \multirow{3}{*}{$\begin{array}{l}\text { Urban } \\
\text { zone }\end{array}$} & \multicolumn{3}{|c|}{ PM10 } & \multicolumn{3}{|c|}{ PM2.5 } \\
\hline & \multirow{2}{*}{$\begin{array}{c}\begin{array}{c}\text { annual } \\
\text { trend }\end{array} \\
{\left[\mu \mathrm{g} / \mathrm{m}^{3}\right]}\end{array}$} & \multirow{2}{*}{$\mathrm{R}^{2}$} & \multirow{2}{*}{$\begin{array}{c}\text { prediction } \\
2020 \\
{\left[\mu \mathrm{g} / \mathrm{m}^{3}\right]}\end{array}$} & \multirow{2}{*}{$\begin{array}{l}\begin{array}{l}\text { annual } \\
\text { trend }\end{array} \\
{\left[\mu \mathrm{g} / \mathrm{m}^{3}\right]}\end{array}$} & \multirow{2}{*}{$\mathrm{R}^{2}$} & $\begin{array}{l}\text { prediction } \\
2020\end{array}$ \\
\hline & & & & & & {$\left[\mu \mathrm{g} / \mathrm{m}^{3}\right]$} \\
\hline Bydgoszcz & 2.2 & $0.7^{\star \star \star}$ & 44.0 & -0.6 & $0.5^{\star}$ & 13.0 \\
\hline Tarnów & 1.1 & 0.1 & 43.0 & -1.1 & $0.6^{\star \star}$ & 20.0 \\
\hline Kraków & -0.5 & 0.0 & 52.0 & -1.2 & $0.6^{\star \star}$ & 27.5 \\
\hline Upper Silesia & -0.7 & 0.2 & 40.5 & 0.0 & 0.0 & 34.0 \\
\hline Rybnik and Jastrzębie-Zdrój & -1.9 & $0.7^{\star \star \star \star}$ & 43.0 & -1.6 & $0.6^{\star \star}$ & 20.5 \\
\hline Łódź & 0.0 & 0.0 & 40.0 & 0.4 & 0.2 & 29.0 \\
\hline Wałbrzych & 0.8 & $0.4^{\star \star}$ & 33.0 & -1.1 & $0.6^{\star \star}$ & 15.0 \\
\hline Elblag & 0.5 & $0.3^{\star \star}$ & 26.0 & -1.0 & $0.7^{\star \star}$ & 11.0 \\
\hline Koszalin & 0.5 & $0.3^{\star \star}$ & 25.5 & 0.0 & 0.0 & 13.0 \\
\hline Radom & 0.1 & 0.0 & 33.0 & -0.4 & 0.3 & 22.0 \\
\hline Włocławek & 0.1 & 0.0 & 32.5 & -0.2 & 0.1 & 19.0 \\
\hline Poznań & -0.1 & 0.0 & 29.0 & -0.4 & 0.3 & 22.0 \\
\hline Szczecin & -0.2 & 0.1 & 24.5 & -0.1 & 0.0 & 15.0 \\
\hline Toruń & -0.3 & 0.0 & 28.0 & -1.6 & 0.4 & 9.5 \\
\hline Wrocław & -0.1 & 0.0 & 36.0 & -0.9 & 0.2 & 20.0 \\
\hline Zielona Góra & -0.2 & 0.1 & 23.0 & -0.5 & 0.2 & 17.0 \\
\hline Bielsko-Biała & -0.7 & $0.3^{\star \star}$ & 34.0 & -2.3 & $0.8^{\star \star \star}$ & 16.5 \\
\hline Gorzów Wlkp. & -0.9 & $0.3^{\star \star}$ & 23.5 & -0.2 & 0.1 & 15.5 \\
\hline Kalisz & -0.6 & 0.1 & 32.0 & -1.4 & $0.7^{\star \star}$ & 20.5 \\
\hline Częstochowa & -0.6 & 0.2 & 31.0 & -1.8 & $0.7^{\star \star}$ & 18.0 \\
\hline Lublin & -0.5 & $0.5^{\star \star \star}$ & 28.0 & -0.1 & 0.0 & 21.3 \\
\hline Białystok & -0.4 & $0.2^{\star}$ & 22.0 & -0.7 & $0.5^{\star}$ & 16.5 \\
\hline Legnica & -0.2 & 0.0 & 33.0 & -1.1 & $0.7^{\star \star}$ & 19.5 \\
\hline Kielce & -0.1 & 0.0 & 35.0 & -2.2 & $0.6^{\star \star}$ & 14.0 \\
\hline Olsztyn & 0.0 & 0.0 & 22.5 & -0.6 & $0.7^{\star \star}$ & 13.5 \\
\hline Opole & -0.6 & $0.3^{\star \star}$ & 28.5 & -0.8 & $0.7^{\star \star}$ & 18.0 \\
\hline Płock & -0.4 & 0.1 & 26.0 & -0.7 & $0.5^{\star}$ & 19.0 \\
\hline Rzeszów & -0.6 & 0.2 & 28.5 & -1.0 & $0.7^{\star \star}$ & 18.0 \\
\hline Tricity & 0.0 & 0.0 & 25.0 & -1.1 & $0.7^{\star \star}$ & 8.5 \\
\hline Warsaw & -0.4 & $0.3^{\star \star}$ & 29.0 & -0.4 & 0.2 & 21.0 \\
\hline Mean & -0.2 & 0.2 & 31.7 & -0.8 & 0.4 & 18.2 \\
\hline
\end{tabular}

significance at the level: $p<0.1^{\star}, p<0.05^{\star \star}, p<0.01^{\star \star \star}$ 

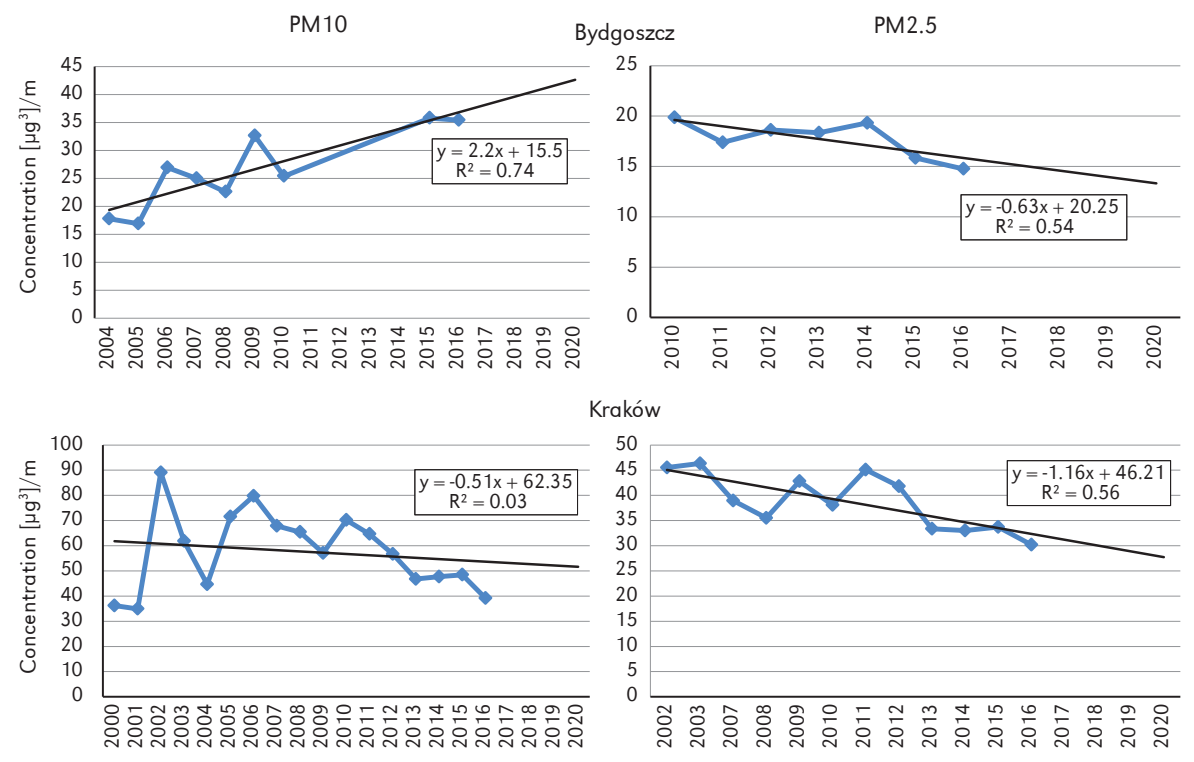

Rybnik and Jastrzębie-Zdrój
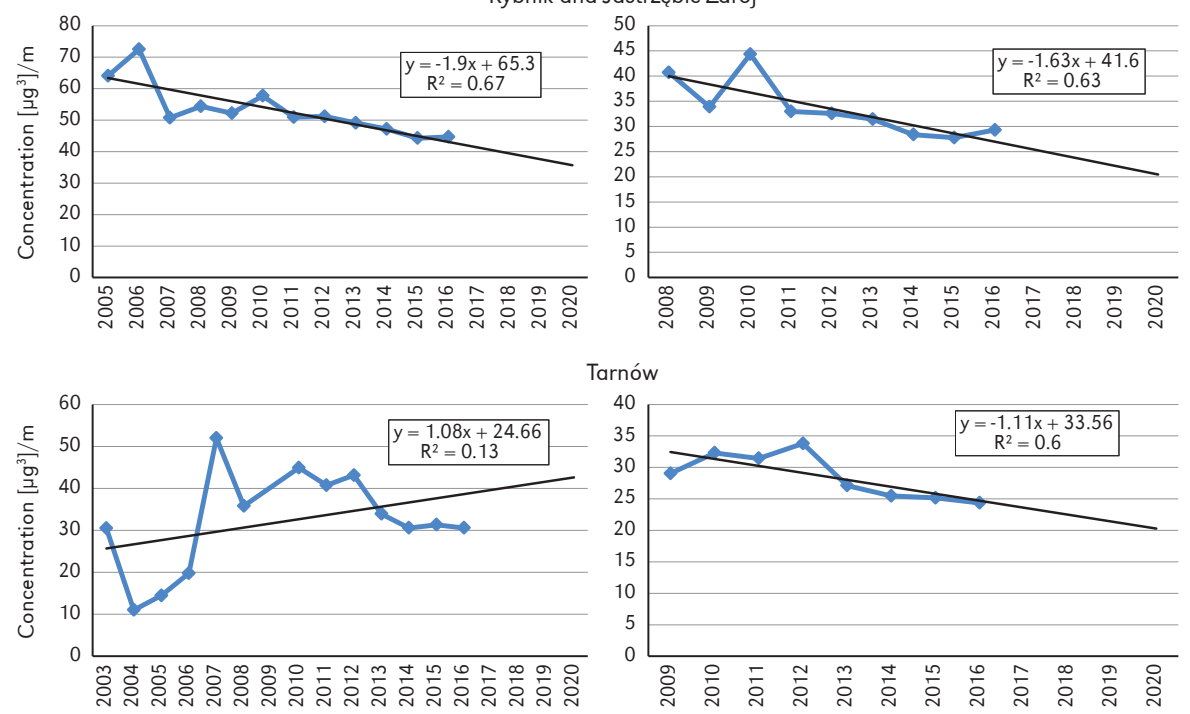

Figure 4. Annual trends in PM10 and PM2.5 concentrations in chosen Polish cities with prediction until 2020

situated in the Silesia Voivodeship is particularly puzzling. In order to reduce the pollution level, it is necessary not only to monitor and assess the trend of changes, but also to identify the reasons of pollution and to prevent them. We need to keep in mind, that the pollution level is not only a resultant of emission volume, but also of the dispersion of pollutants in the atmosphere and their deposition. Examples of such cities as Włocławek, Płock and Tarnów, show that despite a very high emission level, the particulate matter concentration may be low. In these cities, the pollution level is determined by topoclimatic 
conditions related to the ventilation of the city. In the case of Włocławek and Płock, ventilation is facilitated by the wide valley of the Vistula river that crosses these cities. There is no large river valley in Tarnów. The situation in this city proves how important for regulating of PM concentrations is the surface area and localization of agriculture areas with significant areas of natural vegetation. Although the share of forests in this city is low, a large share of small fields (50\%), including meadows and pastures (13\%), densely intersected by hedgerows, makes the concentrations of PM much lower than in cities with similar emission level, e.g. Kraków or Rybnik. Such type of land use can contribute to reducing the spread of pollution, as is the case of green areas in cities. The research of $\mathrm{Wu}$ et al. (2015) and Łowicki (2019) prove that the composition and configuration of particular

\section{References}

Dockery D.W., Pope C.A., Xu X., Spengler J.D., Ware J.H., Fay M.E., Ferris B.G. JR., Speizer FE., 1993. An association between air pollution and mortality in six U.S. cities. New England Journal of Medicine, vol. 329, no. 24, pp. 1753-1759.

DzIenNik Urzędowy Województwa MaŁopolskieGO, 2017. Program ochrony powietrza dla województwa małopolskiego: Małopolska w zdrowej atmosferze. Uchwała nr XXXII/451/17 Sejmiku Województwa Małopolskiego z dnia 23 stycznia 2017 r. [Resolution no. XXXII/451/17 of the Małopolska Regional Assembly of 23 January 2017], Kraków: Urząd Marszałkowski Województwa Małopolskiego.

EEA, 2014. Eionet Central Data Repository. European Environment Agency, http://cdr.eionet. europa.eu/pl/un/EMEP\%20emissions\%20data/ envvyhyeq/ [20 December 2019].

EEA, 2016. Air Quality in Europe - 2016. European Environmental Agency, EEA Report, no. 28/2016, Luxembourg: Publications Office of the European Union.

EUR-LeX, 2008. Directive 2008/50/EC of the European Parliament and of the Council of 21 forms of land-use is, along with the climatic conditions, of crucial importance and this aspect should be considered in spatial planning. Thus, it is necessary to conduct comprehensive analyses of concentration along with analysis of conditions of pollutants spreading and their deposition. In many cities quick parallel actions are needed at three levels: (a) investment, e.g. liquidation of solid fuel boilers, (b) legal, e.g. anti-smog resolutions of provincial governments, (c) planning, e.g. creation and implementation of protection programs and spatial planning taking into account the threats caused by air pollution.

Editors' note:

Unless otherwise stated, the sources of tables and figures are the authors', on the basis of their own research.

May 2008 on ambient air quality and cleaner air for Europe. https://eur-lex.europa.eu/legalcontent/EN/TXT/?uri=celex\%3A32008L0050 [17 December 2018].

GIOŚ, 2011. Analiza stanu zanieczyszczenia powietrza pyłem PM10 i PM2,5 z uwzględnieniem składu chemicznego pyłu oraz wpływu źródeł naturalnych. Zabrze: Główny Inspektorat Ochrony Środowiska.

GIOŚ, 2017a. Stan środowiska w Polsce: Sygnaty 2016. Biblioteka Monitoringu Środowiska, Warszawa: Główny Inspektorat Ochrony Środowiska.

GIOŚ, 2017b. Bank danych pomiarowych. Główny Inspektorat Ochrony Środowiska, http://powietrze.gios.gov.pl/pjp/archives [3 September 2017].

GUS BDL, Statistics Poland, Local Data Bank. https://bdl.stat.gov.pl/BDL/start [16 July 2018].

Juda-Rezler K., Toczko B. (eds.), 2016. Pyły drobne $w$ atmosferze: Kompendium wiedzy o zanieczyszczeniu powietrza pyłem zawieszonym w Polsce. Biblioteka Monitoringu Środowiska, Warszawa: Główny Inspektorat Ochrony Środowiska. 
Langner M., Draheim T., Endlicher W., 2011. Particulate matter in the urban atmosphere: Concentration, distribution, reduction - Results of studies in the Berlin metropolitan Area [in:] W. Endlicher, P. Hostert, I. Kowarik, E. Kulke, J.M. Marzluff, E. van der Meer, H. Mieg, G. Nutzmann, M. Schulz, G. Wessolek (eds.), Perspectives in Urban Ecology: Studies of Ecosystems and Interactions between Humans and Nature in the Metropolis of Berlin, Berlin-Heidelberg: Springer.

ŁowICKI D., 2019. Landscape pattern as an indicator of urban air pollution of particulate matter in Poland. Ecological Indicators, vol. 97, pp. 17-24.

Reizer M., Juda-Rezler K., 2016. Explaining the high PM10 concentrations observed in Polish urban areas. Air Quality, Atmosphere \& Health, vol. 9, no. 5, pp. 517-531.

Rogula-KozŁoWska W., KlejnowskI K., RogulaKopiec P., Ośródka L., Krajny E., BŁaszczak B., Mathews B., 2014. Spatial and seasonal variability of the mass concentration and chemical composition of PM2.5 in Poland. Air Quality, Atmosphere \& Health, vol. 7, no. 1, pp. 41-58.

Rozporzązenie Ministra Środowiska z dnia 24 sierpnia 2012 r. W sprawie poziomów niektórych substancji w powietrzu (Dz. U. z 2012 r., poz. 1031) [Regulation of the Minister of the Environment of 24 August 2012 on Levels of some Pollutants in Air (Journal of laws of 2012, item 1031).

Sówka I., Pachurka Ł., Przepiórka M., RogulaKozłowsKa W., ZwoźDzIAK A., 2016. Assessment of the short-term influence of particulate matter concentrations on the health of the inhabitants of Wroclaw. Annual Set The Environment Protection, vol. 18, pp. 603-615.

SPRAWOZDANIE Z REALIZACJI PROGRAMU OCHRONY POWIETRZA DLA WOJEWÓDZTWA MAŁOPOLSKIEGO ZA OKRES 2013-2015, 2016. [Implementation report on air quality plan for the Małopolska region in the years 2013-2015], Kraków: Urząd Marszałkowski Województwa Małopolskiego.

WHO, 2016. WHO global urban ambient air pollution database. http://www.who.int/phe/ health_topics/outdoorair/databases/cities/en/ [3 September 2017].

Wu J., XIE W., LI W., LI J., 2015. Effects of urban landscape pattern on $P M_{25}$ pollution - A Beijing case study. PLoS One, vol. 10, no. 11, e0142449. 